\title{
PRAVO NA SASLUŠANJE I IZRAŽAVANJE MIŠLJENJA U POSEBNIM OVRŠNIM POSTUPCIMA RADI PREDAJE DJETETA I OSTVARIVANJA OSOBNIH ODNOSA S DJETETOM
}

\author{
Doc. dr. sc. Katarina Knol Radoja*
}

\author{
UDK 347.626:347.952 \\ https://doi.org/10.30925/zpfsr.42.1.9 \\ Ur.: 5. siječnja 2021. \\ Pr.: 24. ožujka 2021. \\ Pregledni rad
}

\begin{abstract}
Sažetak
U radu se analiziraju međunarodni propisi i sudska praksa Europskog suda za ljudska prava i Suda Europske unije te odredbe hrvatskoga Obiteljskog zakona u svezi s pravom na saslušanje i izražavanje mišljenja djeteta $u$ postupku ovrhe radi predaje djeteta $i$ ovrhe radi ostvarivanja osobnih odnosa s djetetom. Sukladno tom Zakonu, u postupku radi predaje djeteta sud može prije određivanja sredstava ovrhe saslušati osobu protiv koje se ovrha provodi. Po pitanju prava djeteta na izražavanje mišljenje u tom postupku propisano je da sud može, s obzirom na okolnosti slučaja tijekom postupka ovrhe, dijete uputi na razgovor sa stručnom osobom. S druge strane, u postupku ovrhe radi ostvarivanja osobnih odnosa s djetetom sud je dužan prije donošenja rješenja zakazati ročište na kojemu će osobno saslušati stranke kako bi utvrdio činjenice i procijenio sve okolnosti te je dužan djetetu omogućiti izražavanje mišljenja. Zaključno se iznosi da postupci radi ovrhe, posebice zbog njihove prirode (osobni i emocionalni), trebaju biti hitni i što jednostavniji. Pri njihovoj provedbi, dijete, kao niti stranke u postupku ne bi trebalo apsolutno onemogućiti u ostvarivanju prava na saslušanje i izražavanje mišljenja. Međutim, sud ne bi trebao biti obvezan održati ročište na kojem će saslušati stranku i omogućiti djetetu izražavanje mišljenje ako to nije nužno za razjašnjenje slučaja. Isto bi trebalo ovisiti o diskrecijskoj ocjeni suda s obzirom na okolnosti slučaja $i$ uvažavajući dobrobit djeteta. Autorica rada stoga predlaže izmjenu odredbe o saslušanju u postupku radi ostvarivanja osobnih odnosa s djetetom na način da sud koji provodi ovrhu može saslušati stranke te omogućiti djetetu izražavanje mišljenja, a sve radi zaštite interesa i dobrobiti djeteta.
\end{abstract}

* Dr. sc. Katarina Knol Radoja, docentica, Pravni fakultet Sveučilišta J. J. Strossmayera u Osijeku; kknol@pravos.hr. ORCID: https://orcid.org/0000-0003-0275-3076.

Ovaj je rad financirao Pravni fakultet Osijek Sveučilišta J. J. Strossmayera u Osijeku internim projektom br. IP-PRAVOS-10 Suvremene tendencije razvoja hrvatskog građanskog pravosuđenja. 
Ključne riječi: pravo na saslušanje; pravo djeteta na izražavanje mišljenja; pravo na pristup sudu; posebni ovršni postupci.

\section{UVOD}

U radu se ukazuje na problem nerazmjernog reguliranja prava djeteta na izražavanje mišljenja u ovršnom postupku radi predaje djeteta i postupku radi ostvarivanja osobnih odnosa s djetetom zbog prekomjernog inzistiranja na ostvarivanje toga prava u ovršnom postupku radi ostvarivanja osobnih odnosa s djetetom. Naime, sukladno s Obiteljskim zakonom, ${ }^{1}$ sud je dužan omogućiti saslušanje stranaka i djeteta $\mathrm{u}$ ovršnom postupku radi ostvarivanja osobnih odnosa s djetetom. S druge strane, kada su u pitanju ovršni postupci radi predaje djeteta isti Zakon propisuje saslušanje osobe protiv koje se ovrha provodi i upućivanje djeteta na stručni razgovor samo kao mogućnost. U okolnostima u kojima su prava djece u pitanju, važno je ne samo sagledati meritum slučaja nego treba uzeti u obzir i kako se pravosudni sustav odnosi prema djeci tijekom cijelog procesa odlučivanja. ${ }^{2}$ Načelo prioritetne zaštite najboljeg interesa i dobrobiti djeteta polazna je točka za bilo koji obiteljski postupak, ${ }^{3}$ pri čemu niti postupci ovrhe nisu iznimka. Uvođenje prava na izražavanje mišljenja djeteta u postupke u kojima sudjeluju djeca možemo ocijeniti iznimno pozitivnim pomakom u ostvarenju prava na saslušanje svih sudionika u postupku pa time ujedno i ostvarenju temeljnoga ljudskog prava na pristup sudu. ${ }^{4} \mathrm{U}$ obzir, međutim, treba uzeti okolnost da su svi sudionici pa tako i dijete već tijekom (izvan)parničnog postupka koji je prethodio ovršnom postupku radi predaje djeteta i ostvarivanja osobnih odnosa $\mathrm{s}$ djetetom imali priliku iznijeti svoje argumentacije.

U radu se analizira pravo na saslušanje i izražavanje mišljenja djeteta koja započinje pregledom stavova doktrine i prakse o tom pravu. Zatim se nastavlja s pregledom međunarodnih i domaćih propisa i sudske prakse u svezi s tim pravom u analiziranim posebnim ovršnim postupcima. Zaključno se iznosi stajalište kako nesrazmjerno reguliranje prava djeteta na izražavanje mišljenja u postupku radi predaje djeteta i postupku radi ostvarivanja osobnih odnosa s djetetom, svoju opravdanost ne nalazi u zadovoljavajućoj mjeri u okolnosti da je ostvarivanje osobnih odnosa s djetetom ponavljajuća, a predaja djeteta jednokratna radnja. Obje radnje

1 Obiteljski zakon, Narodne novine, br. 103/15., 98/19. (dalje: ObZ).

2 Ankie Vandekerckhove i Killian O'Brien, „Child-Friendly Justice: turning law into reality“, ERA Forum 14, br. 4 (2013): 524, https://doi.org/10.1007/s12027-013-0323-y; Ton Liefaard, "Child-friendly justice: protection and participation of children in the justice system", Temple Law Review 88, br. 4 (2016): 905, https://www.templelawreview.org/lawreview/assets/ uploads/2016/08/Liefaard-88-Temp.-L.-Rev.-905.pdf.

3 Tako je još i Hamurabijev zakonik iz 17. stoljeća prije naše ere u članku 186. propisivao: „Ako čovek usvoji malo dete, i pošto ga uzme, ono čezne za svojim ocem i majkom, takvo posvojče neka bude vraćeno u dom svoga oca." Više v. Željko, Bartulović, Povijest prava i države. I. dio - Opća povijest prava i države (Rijeka: Pravni fakultet Sveučilišta u Rijeci, 2014.), 29.

4 Dubravka Hrabar, „Europska konvencija o ostvarivanju dječjih prava - Poseban zastupnik djeteta“, u: Dijete u pravosudnom postupku - Primjena Europske konvencije o ostvarivanju dječjih prava, ur. Gordana Filipović, Davorka Osmak-Franjić (Zagreb: Pravobranitelj za djecu, 2012.), 104. 
uvelike utječu na djetetov život i trebaju se, po pitanju njegova osobnog utjecaja na odluku, podjednako vrednovati. Stranke, ali i dijete, trebaju imati pravo na saslušanje. Međutim, to su svoje pravo već ostvarivali u izvanparničnom ili parničnom postupku koji je prethodio ovršnom pa stoga u svrhu pojednostavljenja tog postupka, sprječavanja njegova odugovlačenja i smanjenja zasigurno prisutnog emocionalnog stresa, pravo na saslušanje i izražavanje mišljenja, u skladu s najboljim interesom djeteta, treba $\mathrm{u}$ oba ovršna postupka biti svedeno na diskrecijsku mogućnost procjene suca koji će u danoj situaciji najbolje moći odvagnuti opravdanost provedbe tih procesnih radnji.

\section{OPĆENITO O NAČELU SASLUŠANJA I PRAVU DJETETA NA IZRAZ̆AVANJE MIS̆LJENJA}

Načelo saslušanja obje strane pojavljuje se ne samo u obliku omogućavanja strankama sudjelovanja u parnici, već i aktiviranja stranaka da poduzmu radnje u postupku. ${ }^{5}$ Pravo na pravično suđenje nalaže da se postupak vodi uz poštovanje pravila o osiguranju slobodnog pristupa sudu, ravnopravnosti i procesnoj ravnoteži stranaka i njihovom pravu na kontradiktorno raspravljanje. ${ }^{6}$ Pravo na pravično suđenje općenito, pa tako i u postupcima koji se tiču prava na poštovanje obiteljskog života iz članka 8. uređeno je člankom 6/1. Europske konvencije za zaštitu ljudskih prava i temeljnih sloboda (dalje: EKLJP). ${ }^{7}$ Ipak, pravo na pravično suđenje nije apsolutno i može se podvrgnuti ograničenjima. U procjeni jesu li određene mjere koje ga ograničavaju razmjerne legitimnom cilju, moraju se uzeti u obzir sve relevantne okolnosti. ${ }^{8}$

Pravo djeteta na izražavanje mišljenja odnosi se na pravo djeteta na aktivno sudjelovanje i saslušanje u sudskim postupcima koji ga se tiču i koji utječu na njegov život (čl. 12. Konvencije o pravima djeteta). ${ }^{9}$ Izričito pravo djeteta na izražavanje mišljenja hrvatski ObZ propisuje u člancima 86. i 360. ${ }^{10}$ Dužnost osoba koje skrbe o djetetu da poštuju mišljenje djeteta proizlazi iz članka 86. ObZ-a. Također, tim se člankom naglašava uzimanje djetetovog mišljenja u obzir sukladno s njegovom dobi i zrelosti. Sukladno tom članku, „u svim postupcima u kojima se odlučuje o nekom djetetovu pravu ili interesu dijete ima pravo na prikladan način saznati važne

5 Geoffrey Samuel, Epistemology and Method in Law (London, New York: Routledge, Taylor \& Francis Group, 2016.), 316.

6 Siniša Triva i Mihajlo Dika, Građansko parnično procesno pravo (Zagreb: Narodne novine, 2004.), 148; također vidi čl. 5/1. Zakona o parničnom postupku, Narodne novine br. 53/91., 91/92., 112/99., 129/00., 88/01., 117/03., 88/05., 2/07., 96/08., 84/08., 123/08., 57/11., 25/13., 89/14., 70/19.

7 Konvencija za zaštitu ljudskih prava i temeljnih sloboda, Protokoli br. 1., 4., 6. i 7. uz tu Konvenciju, Narodne novine, Međunarodni ugovori, br. 18/97.

8 Eva Brems, Human Rights: University and Diversity (Hague: Kluwer Law International, 2001.); Pieter Van Dijk i Fried Van Hoof, Theory and Practice of the European Convention on Human Rights (Haag: Kluwer Law International, 1998.).

9 Konvencija o pravima djeteta, Službeni list SFRJ, br. 14/90., Narodne novine, Međunarodni ugovori, br. 12/93., 20/97.

10 Postupak utvrđivanja mišljenja djeteta iscrpnije je uređen podzakonskim aktom, Pravilnikom o načinu utvrđivanja mišljenja djeteta (Narodne novine, br. 106/14., 5/15., 28/16., 103/15., 123/15.). 
okolnosti slučaja, dobiti savjet i izraziti svoje mišljenje te biti obaviješteno o mogućim posljedicama poštivanja njegova mišljenja“. U postupcima u kojima se odlučuje o osobnim i imovinskim pravima i interesima djeteta, sud je, sukladno stavku 1. članku 360., dužan djetetu omogućiti izražavanje mišljenja, „osim ako se dijete tome protivi“. Treba stoga imati na umu da je pravo na izražavanja mišljenja djetetovo pravo, a ne obveza. ${ }^{11}$ Međutim, izraz „osim ako se dijete tome protivi“ djetetu stavlja nepotreban teret. Odgovornost ne bi smjela biti prebačena na dijete. ${ }^{12}$ Nadalje, sukladno stavku 2. „Sud će omogućiti djetetu da izrazi mišljenje na prikladnom mjestu i u nazočnosti stručne osobe, ako procijeni da je to s obzirom na okolnosti slučaja potrebno“. Iznimka je predviđena stavkom 3. istoga članka prema kojem će djetetu mlađem od četrnaest godina sud biti dužan omogućiti izražavanje mišljenja s pomoću posebnog skrbnika ili stručnjaka. Stavak 4. predviđa iznimku od obveze utvrđivanja mišljenje djeteta, a to je kada za to postoji posebno opravdani razlog. ObZ međutim, ne određuje koji bi to razlog mogao biti, što sudskoj praksi daje široki spektar životnih situacija koje može uzeti u obzir. Slično članku 86. ObZ-a, stavak 5. članka 360., ponovno naglašava potrebu obavještavanja djeteta o postupku i to „na način koji je prikladan njegovoj dobi i zrelosti te ako to ne predstavlja opasnost za razvoj, odgoj i zdravlje djeteta“..... ${ }^{13}$

U raspravama o pravu djeteta na izražavanje mišljenja u postupku općenito prevladavaju dva pitanja: pitanje koje su kognitivne sposobnosti poželjne da bi se moglo ostvariti to pravo i pitanje kojim djetetovim interesima zadovoljava takvo pravo. ${ }^{14}$ Oprečna su stajališta o tome jesu li pravo djeteta da izrazi svoje mišljenje u postupku iz članka 12. Konvencije o pravima djeteta i najbolji interesi djeteta $\mathrm{u}$ smislu članka 3. te Konvencije komplementarni ili proturječni. ${ }^{15}$ Najbolji je interes djeteta pravo djeteta da su njegovi interesi najvažniji na način da se procjenjuju i uzimaju u obzir tijekom svih aktivnosti koje ga se tiču. Odluke koje se donose u djetetovom najboljem interesu trebaju se donositi uzimanjem u obzir niza čimbenika koji se odnose na okolnosti u kojima se dijete nalazi, pri čemu prioritet imaju djetetova sigurnost i dobrobit. ${ }^{16}$ Katkad se najbolji interes djeteta koristi u svrhu poticanja djetetova sudjelovanja i saslušanja u postupku, a u nekim se prigodama

11 Nataša Lucić, „Protection of the right of the child to be heard in divorce proceedings harmonization of Croatian law with European legal standards“, u: Procedural aspects of EU law, ur. Dunja Duić i Tunjica Petrašević (Osijek: Faculty of law Osijek, 2017.), 399.

12 Irena Majstorović, „Ostvarivanje prava djeteta na izražavanje mišljenja - koliko su djeca »vidljiva« u obiteljskim sudskim postupcima u Hrvatskoj?“, Ljetopis socijalnog rada 24, br. 1 (2017): 66, https://doi.org/10.3935/ljsr.v24i1.163.

13 Više v. Slađana Aras Kramar, „Novi pristup uređenju postupka radi razvoda braka u Hrvatskoj“, u: Aktualnosti građanskog procesnog prava - nacionalna $i$ usporedna pravnoteorijska $i$ praktična dostignuća, zbornik radova s međunarodnog savjetovanja, ur. Vesna Rijavec et. al. (Split: Sveučilište u Splitu, Pravni fakultet, 2015.), 235-267.

14 Više v. David Archard, Children: Rights and Childhood (London: Routledge, 1993.).

15 Lucić, Protection of the right of the child to be heard in divorce proceedings, 396.

16 Odbor za prava djeteta, Opći komentar br. 14 (2013.) o pravu djeteta da njegovi ili njeni najbolji interesi moraju imati prednost (čl. 3., st. 1.), usvojio je Odbor na svom šezdeset i drugom zasjedanju (14. siječnja - 1. veljače 2013.), pristup 18. veljače 2021., https://j4c.ba/wp-content/ uploads/2018/02/Opci-komentar-14-najbolji-interes-djeteta.pdf. 
isto smatra suprotnim njegovom najboljem interesu. ${ }^{17}$ Tako neki autori ističu dječju kompetentnost za samostalno stvaranje mišljenja, usprkos njihovoj (financijskoj, pravnoj) ovisnosti. Smatraju da bi to trebalo biti dio uobičajenog postupka u bilo kojoj obitelji ako su u pitanju uvjeti života djeteta. ${ }^{18}$ Neki autori smatraju ipak da pravo djeteta na izražavanje mišljenja ovisi o njegovoj dobi. Na ovu temu autori vrlo slično izražavaju pragmatične pretpostavke. Argumenti većina autora podudarni su u tome što ističu nužnost biti u stanju razumjeti situaciju kao i razloge koji su potaknuli trenutni postupak odlučivanja. Prije svega, formuliraju stav da se potrebna sposobnost prosuđivanja razvija s godinama, pa primjerice, zagovaraju da djecu treba testirati prije saslušanja na sudu, pri čemu je za očekivati da će starija djeca lakše proći taj test od mlađe. ${ }^{19}$ Prema nekim autorima, tek u određenoj dobi djeca će steći potrebno razumijevanje situacije koja se zahtijeva za sudjelovanje $u$ donošenju odluka. ${ }^{20}$ Ove i slične linije razmišljanja dokaz su pragmatične pretpostavke da su potrebne kompetencije za ostvarivanje prava na sudjelovanje uglavnom kompetencije koje se mogu razviti. Iz ove se pretpostavke čini legitimnim odgoditi prava koja se parnično sposobnim osobama daju po definiciji. ${ }^{21} \mathrm{~S}$ druge strane, iz perspektive dobrobiti djeteta prema kojoj treba odgovoriti na potrebe svakoga djeteta, žele se izbjeći situacije da odluke za djecu donose drugi, bez njihova prava na mišljenje, tvrdeći da djeca kao rezultat toga mogu razviti probleme privrženosti i osjećaj nemoći. ${ }^{22}$ Međutim, perspektiva dobrobiti djeteta katkad zahtijeva i mogućnost odbijanja dječjih želja. Konvencijom o pravima djeteta potvrđeno je da su djeca subjekti ljudskih prava, a ne samo subjekti zaštite. Time je između djece i države stvorena izravna veza, bez potrebe djelovanja roditelja ili skrbnika kao posrednika. ${ }^{23}$ Ipak, doktrina i praksa pretežnog su stajališta da ostvarenje prava djeteta na izražavanje mišljenje treba provesti posredno (putem roditelja, zastupnika, centra za socijalnu skrb), a ne neposredno na sudu. Time bi se izbjeglo nepotrebno izlaganje stresu, budući da izražavanje mišljenja izravno pred sucem ne pridonosi nužno višoj razini ostvarenja zaštite, ${ }^{24}$ a kontakt u posebnim

17 Jantine Hemrica, Frieda Heyting, „Tacit Notions of Childhood: An Analysis of Discourse about Child Participation in Decision-Making Regarding Arrangements in Case of Parental Divorce“, Childhoods 11, br. 4 (2004): 456, https://doi.org/10.1177/0907568204047106.

18 Više v. Michael Freeman, „Why It Remains Important to Take Children's Rights Seriously“, International Journal of Children's Rights 15, br. 1 (2007): 5-23, https://doi. org/10.1163/092755607X181711.

19 Više v. Ian Young, The Child Client, Children and Society 6, br. 3 (1992): 187-203, https://doi. org/10.1111/j.1099-0860.1992.tb00586.x.

20 Hemrica, Heyting, Tacit Notions of Childhood, 458.

21 Hemrica, Heyting, Tacit Notions of Childhood, 458.

22 Hemrica, Heyting, Tacit Notions of Childhood, 458.

23 Meda Couzens, „Autonomy rights versus parental autonomy“, u: The UN Children's Rights Convention: theory meets practice, eds. André Alen et al. $2^{\text {nd }}$ ed. (Antwerpen; Oxford: Intersentia, 2007.), 407.

24 Paula Poretti, „Pristup pravosuđu za djecu“, u: Prekogranično kretanje djece u Europskoj uniji, ur. Mirela Župan (Osijek: Pravni fakultet Sveučilišta J. J. Strossmayera u Osijeku, 2019.), 78; Aleksandra Korać Graovac i Ivana Eterović, „Pravo djeteta na izražavanje mišljenja“, u: Vodič za ostvarivanje prava djeteta na: - informacije, - izražavanje mišljenja, - zastupnika $i$ - prilagođen postupak u sudskim postupcima razvoda braka i o roditeljskoj skrbi, ur. Slađana Aras Kramar et al. (Zagreb: Hrvatski pravni centar, 2015.), 40. 
neformalnijim prostorijama izvan sudnice, zasigurno je manje stresan za dijete. ${ }^{25}$ Tako je utvrdio i Europski sud za ljudska prava ${ }^{26}$ (dalje: ESLJP) u predmetu Sahin protiv Njemačke. ${ }^{27} \mathrm{U}$ tom se predmetu ESLJP oslonio na objašnjenje vještaka saslušanog pred sudom u Njemačkoj, koji je donio odluku bez saslušanja djeteta o želji za viđanjem oca. Nakon nekoliko susreta sa strankama i djetetom, stručnjak je zaključio da bi ispitivanje djeteta na sudu bilo rizik koji se ne bi mogao zaobići niti posebnom organizacijom na sudu. ${ }^{28}$ Iznosi, da nacionalni sud nije prekoračio svoju slobodu procjene kada se oslanjao na nalaze stručnjaka, čak i u nedostatku izravnih pitanja o djetetovom odnosu s roditeljem. ${ }^{29}$ Sud je stoga zaključio da u tim okolnostima procesni uvjet saslušanja djeteta ne obvezuju na izravno ispitivanje djeteta. ${ }^{30} \mathrm{Da}$ je pod određenim okolnostima nepružanje mogućnosti pristupa sudu djetetu u skladu s njegovim najboljim interesom potvrđeno je i u predmetu Sommerfeld protiv Njemačke. U tom predmetu, ESLJP iznosi da se, određujući je li odbijanje pristupa bilo ,neophodno u demokratskom društvu“, mora razmotriti jesu li, u svjetlu slučaja u cjelini, razlozi navedeni za opravdanje ove mjere relevantni i dostatni za potrebe članka 8/2. EKLJP. Razmatranje onoga što je u najboljem interesu djeteta presudno je u svakom slučaju ove vrste. ${ }^{31} \mathrm{Uz}$ to, Sud naglašava i činjenicu da je dijete već ranije bilo ispitano pred sudom, te smatra da su ispunjeni postupovni zahtjevi implicirani u članku 8. EKLJP. ${ }^{32}$

\section{MEĐUNARODNI IZVORI PRAVA NA SASLUŠANJE I PRAVA DJETETA NA IZRAŽAVANJE MIŠLJENJA U POSTUPCIMA RADI PREDAJE I OSTVARIVANJA OSOBNIH ODNOSA S DJETETOM}

Međunarodni izvori prava na saslušanje u postupku i prava djeteta na izražavanje mišljenja u postupcima koji se tiču predaje djeteta i ostvarivanja osobnih odnosa s djetetom obuhvaćaju čitav niz međunarodnih dokumenata: ${ }^{33}$

- Europsku konvenciju o ljudskim pravima iz 1950.,

- Konvenciju o pravima djeteta iz 1989.

- Hašku konvenciju o građanskopravnim aspektima međunarodne otmice djece iz 1980. (dalje: Haška konvencija o otmici djece), ${ }^{34}$

25 Majstorović, Ostvarivanje prava djeteta na izražavanje mišljenja, 65.

26 Za sudsku praksu ESLJP-a koja se odnosi na pravo djeteta na izražavanje mišljenja vidi, npr. presuda od 26. veljače 2002., Kutzner protiv Njemačke, zahtjev br. 46544/99; presuda od 8 . srpnja 2003., Sahin protiv Njemačke [GC], zahtjev br. 30943/96; presuda od 8. srpnja 2003., Sommerfeld protiv Njemačke [GC], zahtjev br. 31871/96., presuda od 2. svibnja 2019.

27 Presuda od 8. srpnja 2003., Sahin protiv Njemačke [GC], zahtjev br. 30943/96.

28 Sahin protiv Njemačke [GC], para. 74.

29 Sahin protiv Njemačke [GC], para. 75.

30 Sahin protiv Njemačke [GC], para. 77.

31 Sommerfeld protiv Njemačke [GC], zahtjev br. 31871/96, para. 62. i 88.

32 Sommerfeld protiv Njemačke [GC], para. 72.-74.

33 Više v. Branka Rešetar, „Pravo djeteta na ostvarivanje osobnih odnosa u međunarodnom pravu“", u: Prekogranično kretanje djece u Europskoj uniji, ur. Mirela Župan (Osijek: Pravni fakultet Sveučilišta J. J. Strossmayera u Osijeku, 2019.), 229-258.

34 Haška konvencija o građanskopravnim vidovima međunarodne otmice djece, Narodne novine, 
- Hašku konvenciju o nadležnosti, mjerodavnom pravu, priznanju, ovrsi i suradnji u predmetima o roditeljskoj skrbi te mjerama za zaštitu djece iz 1996. (dalje: Haška konvencija o zaštiti djece) ${ }^{35}$ te

- Europsku konvenciju o kontaktima s djecom iz 2003. (dalje: Konvencija o kontaktima). ${ }^{36}$

Na razini Europske unije (dalje: EU) na ovaj popis uvrštavamo i Povelju o temeljnim pravima EU iz 2000. (dalje: Povelja EU), ${ }^{37}$ Uredbu o nadležnosti, priznanju i ovrsi sudskih odluka u bračnim predmetima i predmetima roditeljske odgovornosti iz 2003. (dalje: Uredba 2201/2003) 38 te njezinu nedavnu preinaku Uredba Vijeća (EU) 2019/1111 od 25. lipnja 2019. o nadležnosti, priznavanju i izvršenju odluka u bračnim sporovima i u stvarima povezanima s roditeljskom odgovornošću te o međunarodnoj otmici djece (Preinaka) $)^{39}$ o kojima će više riječi biti infra.

EKLJP temeljni je međunarodni dokument o ljudskim pravima. Iako ne govori izrijekom o pravu na ostvarivanje osobnih odnosa s djetetom, to se pravo može izvesti iz članka 8. o pravu na obiteljski život. ${ }^{40}$ Ipak, ESLJP pravo na poštovanje obiteljskog i privatnog života iz članka 8 . EKLJP ne tumači nužnim provođenjem saslušanja djeteta u sudskom postupku. To pravo nije apsolutno i sudovi nisu pod svaku cijenu obvezni saslušati dijete. Mogućnost saslušanja razmatra se u kontekstu okolnosti svakog slučaja, a posebice uzimajući u obzir zrelost i dob djeteta u pitanju. ${ }^{41} \mathrm{U}$ svojim je presudama taj Sud više puta naglasio da se postupci u vezi s predajom djece i ostvarivanja osobnih odnosa, uključujući i izvršenje tih odluka, moraju hitno rješavati jer je ponajprije $u$ interesu djeteta da se pitanja u svezi s njegovom budućnosti brzo riješe kako bi se smanjila neizvjesnost. Uz to, odugovlačenje i dugotrajnost ovih

br. $8 / 18$.

35 Haška konvencija od 19. listopada 1996. o nadležnosti, mjerodavnom pravu, priznanju, izvršenju i suradnji u vezi s roditeljskom skrbi i mjerama za zaštitu djece, Narodne novine, br. $5 / 09$.

36 Europska konvencija o kontaktima s djecom, Narodne novine, br. 7/08.

37 Povelja Europske unije o temeljnim pravima, 2012/C 326/02, Službeni list C 326 od 26.10. 2012, str. 391-407.

38 Uredba Vijeća (EZ) br. 2201/2003 od 27. studenoga 2003. o nadležnosti, priznavanju i izvršenju sudskih odluka u bračnim sporovima i u stvarima povezanim s roditeljskom odgovornošću, kojom se stavlja izvan snage Uredba (EZ) br. 1347/2000. SL 338/1. od 23.12.2003, p. 1-29.

39 Uredba (EU) 2019/1111 od 25. lipnja 2019. o nadležnosti, priznavanju i izvršenju odluka u bračnim sporovima i u stvarima povezanima s roditeljskom odgovornošću te o međunarodnoj otmici djece (Preinaka), SL EU L178/1.

40 1. Svatko ima pravo na poštovanje svoga privatnog i obiteljskog života, doma i dopisivanja. 2. Javna vlast se neće miješati u ostvarivanje tog prava, osim u skladu sa zakonom $i$ ako je to u demokratskom društvu nužno radi zaštite interesa državne sigurnost, javnog reda i mira, ili gospodarske dobrobiti zemlje, te radi sprječavanja nereda ili zločin, radi zaštite zdravlja ili morala ili radi zaštite prava i sloboda drugih (čl. 8. EKLJP). Više v. Aoife Daly, „The right of children to be heard in civil proceedings and the emerging law of the European Court of Human Rights“, The International Journal of Human Rights 15, br. 3 (2011): 441, https://doi. org/10.1080/13642980903542710; Geraldine Van Bueren, Child Rights in Europe: Convergence and Divergence in Judicial Protection (Strasbourg: Council of Europe Publishing, 2007.).

41 Priručnik o pravima djeteta u europskom pravu, pristup 28. prosinca 2020.https://fra.europa. eu/hr/publication/2020/prirucnik-o-pravima-djeteta-u-europskom-pravu, 41. 
postupaka može neminovno ostaviti posljedice na odnose između roditelja i djeteta. ${ }^{42}$

Konvencija o pravima djeteta prva je konvencija koja izričito predviđa da djetetu koje je sposobno izraziti mišljenje treba pružiti priliku biti saslušano (arg. ex. čl. 12. Konvencije o pravima djeteta). U Konvenciji sposobnost djeteta za donošenje odluka nije stavljena u ovisnost provedbe ove odredbe, ali se u Komentaru UN komisije o pravima djeteta zalaže da se to pitanje utvrdi od slučaja do slučaja. ${ }^{43}$ Prema toj Konvenciji u postupcima u kojima se odlučuje o pravima djece, prednost treba imati najbolji interes djeteta te se trebaju provoditi humano, primjereno i hitno (arg. ex. čl. 3. i 10. Konvencije o pravima djeteta).

Budući da se u ovome radu ponajprije bavimo pitanjem izvršenja odluka radi predaje djeteta i ostvarivanja osobnih odnosa s djetetom, možemo uočiti da, od međunarodnih dokumenata, Haška konvencija o zaštiti djece obuhvaća najvažnije procesne odredbe o zaštiti tih prava s međunarodnim obilježjem. Glavni je cilj ove Konvencije bio otkloniti nedostatke Konvencije o međunarodnoj otmici djece, s obzirom na to da su u njoj uključene i procesne odredbe. ${ }^{44}$ Ovom se Konvencijom mogućnost međusobnog priznanja i ovrhe odluka u državama koje su njezine stranke izričito predviđa i uređuje. Strane se odluke u državama strankama Konvencije u pravilu automatski priznaju i ovrše uz konvencijski zahtjev za jednostavnim i hitnim postupanjem. ${ }^{45}$ Zahtjev za priznanjem i ovrhom odluka može se ipak i odbiti. Ti su razlozi taksativno navedeni u članku 23/2., a to su, između ostalog, ako je mjera poduzeta bez pružanja djetetu i osobi kojoj se tom mjerom zadire u pravo na roditeljsku skrb te mogućnosti da budu saslušani (osim u slučaju hitnosti).

\subsection{Izvršivost sudskih odluka koje se odnose na pravo kontakta s djetetom i predaju djeteta na području EU-a}

Sud EU-a prepoznao je da se kroz sve aktivnosti EU-a moraju poštovati temeljna prava i naglasio da bi pritom i Konvenciji o pravima djece trebalo dati odgovarajuću pozornost. ${ }^{46}$ Člankom 24/1. Povelje EU-a propisano je da djeca mogu slobodno izražavati mišljenja koja će se, u stvarima koja se na njih odnose, uzeti u obzir u skladu s njihovom dobi i zrelosti. Pitanje izvršivosti sudskih odluka koje se odnose na pravo kontakta s djetetom i kojima se zahtijeva predaja djeteta na području EU-a

42 Vidi odluke u predmetima: presuda od 25. siječnja 2000., Ignaccolo-Zenide protiv Rumunjske, zahtjev br. 31679/96; presuda od 26. lipnja 2003., Maire protiv Portugala, zahtjev br. 48206/99; presuda od 7. ožujka 2013., Raw protiv Francuske, zahtjev br. 10131/11.

43 UN Committee on the Rights of the Child (CRC), General comment No 12 (2009): The right of the child to be heard, 20 July 2009, CRC/C/GC/12, str. 12.

44 Više v. William Duncan, ,Action in support of the Hague child abduction convention: A view from the Permanent bureau", International Law and Politics 33, br. 103 (2001): 103-123, https:// heinonline.org $/ \mathrm{HOL} /$ LandingPage?handle=hein.journals/nyuilp33\&div=14\&id=\&page=

45 Rešetar, Pravo djeteta na ostvarivanje osobnih odnosa u međunarodnom pravu, 241.

46 Rebecca O'Donnell, „The role of the EU legal and policy framework in strengthening child friendly justice“, ERA Forum 14, br. 4 (2013): 507-521, https://doi.org/10.1007/s12027-0130328-6. Za sudsku praksu Suda EU-a koja se odnosi na pravo djeteta na izražavanje mišljenja vidi, npr. presuda od 22. prosinca 2010. Aguirre Zarraga v Pelza, Case C-491/10 [2010] ECR I-14247; presuda od 5. listopada 2010. $M c B v$ L.E., Case C-400/10 [2010] ECR I-8965. 
iscrpno je uređeno Uredbom 2201/2003. ${ }^{47}$ Nova Uredba - Preinaka će se, sukladno prijelaznim odredbama u članku 100. Preinake, ,primjenjivati na pokrenute sudske postupke, na autentične isprave koje su službeno sastavljene ili upisane u registar te na sporazume upisane u registar 1 . kolovoza 2022. ili nakon tog datuma“. Uredba 2201/2003 stoga je i dalje primjenjiva na sudske odluke i autentične isprave donesene prije 1. kolovoza 2022.

Iz Uredbe 2201/2003 jasno proizlazi da saslušanje stranaka i $\operatorname{djeteta~}^{48}$ u postupcima o pravu kontakta s djetetom i predaji djeteta ima važnu ulogu. Naime, sukladno članku 41.i 42. Uredbe, prava na kontakt s djetetom te predaju djeteta priznata u ovršnoj sudskoj odluci, priznaju se i izvršiva su u drugoj državi članici bez potrebe ishođenja potvrde izvršivosti i bez mogućnosti propitivanja njihova priznavanja, ako je potvrđena u državi članici podrijetla. Međutim, potvrda koju izdaje sudac države podrijetla o pravu na kontakt s djetetom, kao i izdavanje potvrde za predaju djeteta uvjetovano je, između ostalog, okolnosti da je strankama dana mogućnost biti saslušane te da je djetetu, primjereno dobi i zrelosti, omogućeno saslušanje ( $\arg$. ex. čl. 41/2. i 42/2. Uredbe 2201/2003). Tako primjerice i Županijski sud u Zagrebu utvrđuje bitnu povredu odredaba postupka zbog povrede načela saslušanja stranaka jer sud nije saslušao predlagatelja i ukazuje na članak 11. Uredbe 2201/2003. Njime je propisano da sud ne može odbiti predaju djeteta, a da prije toga ne pruži mogućnost saslušavanja osobe koja zahtijeva njegovu predaju. Uz to, iznosi i da prvostupanjski sud nije naveo razloge zašto nije saslušao dijete, iako je Uredbom 2201/2003 propisano da dijete ima mogućnost saslušanja tijekom postupka, osim ako se to čini neprikladnim zbog njegove dobi ili stupnja zrelosti. ${ }^{49}$

Postupak izvršenja, sukladno članku 47. Uredbe 2201/2003, uređuje pravo države članice izvršenja. Izvršenje se u državi članici izvršenja provodi pod istim pretpostavkama kao i kad bi bila izrečena u toj državi članici. U predmetu Doris Povse protiv Mauro Alpago ${ }^{50}$ Sud EU-a ističe da nakon izdavanja potvrde o izvršenju ne postoji opcija suprotstavljanja odluci jer se potvrda provodi automatski. ${ }^{51}$ Samo sudovi države podrijetla imaju nadležnost za odlučivanje o njezinu učinku na djetetove najbolje interese. Uz pretpostavku da ti sudovi taj rizik drže utemeljenim, oni zadržavaju isključivu nadležnost obustave vlastite odluke o izvršenju. ${ }^{52}$ Dapače, ako se tijekom ovršnog postupka u državi izvršenja utvrdi da tijekom postupka u državi podrijetla dijete nije bilo saslušano, unatoč tome što je na potvrdi o izvršenju upisano da je, to neće dati mogućnost osporavanja merituma odluke u državi izvršenja. U svezi s navedenim, u predmetu Joseba Andoni Aguirre Zarraga protiv Simone Pelz ${ }^{53}$

47 Uredba Vijeća (EZ) br. 2201/2003 od 27. studenoga 2003. o nadležnosti, priznavanju i izvršenju sudskih odluka u bračnim sporovima i u stvarima povezanim s roditeljskom odgovornošću, kojom se stavlja izvan snage Uredba (EZ) br. 1347/2000. SL 338/1. od 23.12.2003.

48 Čl. 11/2., čll. 23. b), čl. 41/2. c) i čl. 42/2. a).

49 Presuda Županijskog suda u Zagrebu br. Gž Ob-600/16 od 10. svibnja 2016. godine.

50 Presuda od 1. srpnja 2010., Doris Povse protiv Mauro Alpago, C-211/10, ECLI:EU:C:2010:400.

51 Doris Povse protiv Mauro Alpago, para. 70.

52 Doris Povse protiv Mauro Alpago, para. 77., 82.

53 Presuda od 22. prosinca 2010. Joseba Andoni Aguirre Zarraga protiv Simone Pelz, C-491/10 PPU, ECLI:EU:C:2010:828. 
od Suda EU-a zatraženo je mišljenje o tome može li sud države izvršenja osporiti nalog za izvršenje države podrijetla zato što dijete nije saslušano, čime su prekršene odredbe članka 24. Povelje EU-a i članka 42/2. Uredbe 2201/2003. ${ }^{54}$ Sud EU-a ustvrdio je da pravo djeteta na saslušanje nije apsolutno, nego se procjenjuje u skladu s njegovim najboljim interesom..$^{55}$ Naime, ono što je u presudi ključno je da, Sud iznosi mišljenje da saslušanje djeteta u određenim okolnostima može biti čak i štetno za njegovo psihološko zdravlje jer su takvi sudski postupci često popraćeni tenzijama. Slijedom toga, budući da sukobi o kojima se odlučuje u obiteljskim predmetima stvaraju situacije u kojima se saslušanje djeteta može pokazati neprimjerenim, pa čak i štetnim za psihološko zdravlje djeteta te na njih negativno utjecati, sud koji donosi odluku o djetetu mora procijeniti je li takvo ročište uputno. Sukladno tomu, iako ostaje djetetovo pravo, saslušanje djeteta ne može biti apsolutna obveza, već se mora procijeniti uzimajući u obzir ono što je u najboljem interesu djeteta u svakom slučaju, u skladu s člankom 24/2. Povelje EU-a. ${ }^{56}$ Uz to, prema mišljenju Suda, u skladu s načelom međusobnog povjerenja, prema kojem su pravni sustavi država članica obvezni pružiti podjednaku zaštitu temeljnih prava, samo sudovi države podrijetla djeteta smiju ispitati zakonitost svojih vlastitih presuda. Vlasti države izvršenja ne mogu se protiviti izvršenju strane odluke o povratku djeteta, pa čak niti na temelju nepoštovanja njegovog prava na saslušanje u državi podrijetla. ${ }^{57}$

\section{OVRHA RADI PREDAJE DJETETA I RADI OSTVARIVANJA OSOBNIH ODNOSA S DJETETOM U REPUBLICI HRVATSKOJ}

U Republici Hrvatskoj (dalje: RH) u svim (izvan)parničnim postupcima koji prethode donošenju ovršne isprave propisana je dužnost suda da sasluša stranke $i$ omogući djetetu izražavanje mišljenja. Sukladno Ustavu $\mathrm{RH}^{58}$ svatko ima prava i slobode te vrijedi jednakost svih pred zakonom (arg.ex. čl. 14. i 29. Ustava RH). Posebnost postupaka u kojima se odlučuje o djetetovom stanovanju i ostvarivanju osobnih odnosa s njime je u ograničenim dispozicijama stranaka i većim istražnim ovlaštenjima suda. Naime, sukladno ObZ-u u tim postupcima sud nije vezan zahtjevima stranaka, što znači da može odlučiti i protiv volje stranaka (čl. 409. ObZ), međutim, to ne smije značiti da nisu imali priliku iskazati ju. Tako i Županijski sud u Zagrebu iznosi „kada sud donosi odluku o privremenoj mjeri o tome s kojim će roditeljem dijete živjeti, i koja mjera će biti na snazi sve do okončanja posebnog parničnog postupka kojim će se to pitanje konačno riješiti, tada je sud pri donošenju odluke o privremenoj mjeri dužan omogućiti roditelju kao protivniku osiguranja da se očituje, odnosno sud je dužan pozvati roditelja-protivnika osiguranja kao stranku postupka da iznese sve tvrdnje i prijedloge, radi valjanog utvrđenja činjeničnog stanja na kojem će se temeljiti odluka o privremenoj mjeri, te ukoliko sud tako ne postupi

54 Joseba Andoni Aguirre Zarraga protiv Simone Pelz, para. 28.

55 Joseba Andoni Aguirre Zarraga protiv Simone Pelz, para. 64.

56 Joseba Andoni Aguirre Zarraga protiv Simone Pelz, para. 64.

57 Joseba Andoni Aguirre Zarraga protiv Simone Pelz, para. 69., 70.

58 Ustav Republike Hrvatske, Narodne novine, br. 85/10., 05/14. 
tada čini bitnu povredu odredaba postupka i stoga je takva odluka suda nezakonita". ${ }^{59}$

Ovršni postupak u RH podrobno propisuje opći propis - Ovršni zakon, ${ }^{60}$ ali osim njega, taj je postupak uređen i nizom posebnih zakona. Budući da je u ovom radu riječ o specifičnom obiteljskopravnom odnosu, sukladno načelu lex specialis derogat legi generali jedine mjere koje se u ovršnim postupci radi predaje djeteta i radi ostvarivanja osobnih odnosa s djetetom mogu izricati jesu mjere predviđene ObZ-om, a ne one propisane Ovršnim zakonom. ${ }^{61}$ Međutim, da bi se jasnije ukazalo na odnos ostvarenja prava na saslušanje u redovitom postupku u odnosu na ovršni, nužno je ukazati na okolnost da u općem ovršnom postupku pravo na saslušanje trpi znatna ograničenja. Naime, sukladno općim pravilima ovršnog prava, sud je ovlašten odlučiti o prijedlogu za ovrhu i prije nego što je protivniku omogućeno da se očituje o njemu. Sud može i započeti s provedbom ovrhe i prije nego što je protivniku pružena ta mogućnost. Dika smatra kako razlog takvog potiskivanja načela saslušanja u ovršnom postupku treba tražiti u okolnosti da je strankama već u prethodnom kognicijskom postupku bilo omogućeno iznijeti svoje stavove, pa je smanjena opasnost od zloupotrebe. Pritom smatra to opravdanim zbog sprječavanja onemogućavanja ostvarenja ovrhe. ${ }^{62} \mathrm{Na}$ obvezu davanja mogućnosti stranci da se izjasni u ovršnom postupku ukazuje samo ako ovrsi nije prethodio kognicijski postupak, kao primjerice u postupcima ovrhe na temelju vjerodostojne isprave. ${ }^{63}$

Ovrha radi predaje djeteta uređena je člancima 512.-519. ObZ-a. Nakon završetka (izvan)parničnog postupka, prije nego što odredi sredstva ovrhe radi predaje djeteta sud može, ako procijeni da je to svrsishodno, saslušati osobu protiv koje se ovrha provodi. S obzirom na okolnosti slučaja tijekom postupka ovrhe također može uputiti dijete na razgovor kod stručne osobe (čl. 517. ObZ). Valja dakle istaknuti, da je odredbom članka 517. ObZ-a propisana mogućnost, a ne i obveza, saslušavanja i upućivanja na razgovor. ObZ prije njegovih posljednjih važnih izmjena 2015. nije obuhvaćao posebne odredbe o saslušanju u ovom ovršnom postupku. Međutim, neki su sudovi ipak provodili saslušanje pozivajući se na čl. 89/5. ObZ-a kojim su djeca imala pravo na primjeren način saznati bitne okolnosti slučaja, dobiti savjet i izreći svoje mišljenje te biti obaviještena o mogućim posljedicama njihovog mišljenja, koje se uzimalo u obzir u skladu s dobi i zrelosti djeteta te na članak 12. Konvencije o pravima djeteta. Tako i u presudi donesenoj na temelju odredaba „starog ObZ“664 Županijski sud u Varaždinu iznosi da „obzirom na suprotstavljene tvrdnje ovrhovoditeljice i ovršenika po ocjeni ovog suda radi utvrđivanja odlučne činjenice postupa li ili ne ovršenik po nalogu suda iz pravomoćnog rješenja o ovrsi bilo je potrebno saslušati djecu stranaka bilo izravno na sudu uz pomoć psihologa ili preko nadležnog centra za socijalnu skrb. Sve to zato što predaja djeteta ne može u svakom pojedinom slučaju ovisiti o

59 Županijski sud u Zagrebu u presudi od 27. prosinca 2019., br. Gž Ob 1371/2019-2.

60 Ovršni zakon, Narodne novine, br. 112/12., 25/13., 93/14., 55/16., 73/17., 131/20.

61 Tako iznosi i Županijski sud u Bjelovaru u svojoj odluci broj: Gž-278/09-2 od 26. ožujka 2009.

62 Mihajlo Dika, Građansko ovršno pravo, Opće građansko ovršno pravo (Zagreb: Narodne novine, 2007.), 51.

63 Dika, Građansko ovršno pravo, 51.

64 Obiteljski zakon, Narodne novine, br. 116/03., 17/04., 106/04., 136/04., 107/07., 57/11., 61/11. i 25/13. (dalje: „stari ObZ“). 
isključivoj volji roditelja koji ga je dužan predati drugom roditelju“ “65

Vezano za postupke ovrhe odluka o osobnim odnosima roditelja i djece (čl. 520.525. ObZ), iako je riječ o različitim postupcima, do donošenja ObZ-a 2015. „stari ObZ“ iz 2003. godine uređivao je samo u članku 353. upućivanje na odgovarajuću primjenu odredbi o ovrsi radi predaje djeteta. Razlika između tih postupaka je u tome što se ovrhom radi ostvarivanja osobnih odnosa prisilno ostvaruju ponavljajući osobni odnosi između roditelja i djece, dok se ovrha radi predaje djeteta ostvaruje jednom radnjom. ${ }^{66}$ Stoga je apsolutno opravdano zasebno urediti ove dvije vrste ovrhe. Međutim, po jednoj razlici ovi postupci ipak previše odskaču jedan od drugog bez jasno vidljivog i opravdanog razloga. Naime, sukladno članku 522. ObZ-a sud prije donošenja rješenja o ovrsi radi ostvarivanja osobnih odnosa s djetetom mora održati ročište na kojemu će radi utvrđivanja svih činjenica i okolnosti konkretnoga slučaja osobno saslušati stranke te na kojem će djetetu omogućiti da izrazi svoje mišljenje. ${ }^{67}$ Sud je, dakle obvezan zakazati ročište, dok u postupcima radi predaje djeteta zakazivanje ročišta je propisano samo kao mogućnost, koja ovisi o diskrecijskoj ocjeni suda. U oba slučaja, ovrsi je prethodio (izvan)parnični postupak u kojem je sud bio obvezan omogućiti strankama saslušanje i djetetu izražavanje mišljenje. Ponovno obvezivanje suca i ostalih sudionika čak i kada okolnosti slučaja to ne zahtijevaju, nepotrebno je i suviše odugovlači postupak koji bi, po prirodi stvari, trebao biti hitan i jednostavan. Zasigurno možemo smatrati opravdanim diskrecijsku mogućnost provođenja saslušanja u ovršnom postupku kada to zahtijevaju okolnosti slučaja i potrebe zaštite najboljeg interesa djeteta, međutim, ne i za postojanje takve obveze koja često dovodi do odgađanja ovrhe i time njezinog odugovlačenja.

Mogućnost odgode ovrhe ObZ predviđa u oba slučaja ovrhe. U postupcima radi ostvarivanja osobnih odnosa s djetetom nakon provedenog ročišta i saslušanja, sud može s obzirom na okolnosti slučaja i za trideset dana odgoditi ovrhu i naložiti stručni razgovor s djetetom ili strankama predložiti pokušaj sporazumnog rješenja spora u obiteljskoj medijaciji (čl. 522. ObZ). Ovrhu radi predaje djeteta sud može, između ostalog, odgoditi i kada se djetetu nalaže stručni razgovor (čl. 519. ObZ). Kao preventivne mjere ObZ ipak uspostavlja dodatne pretpostavke za odgodu i to u postupcima ovrhe radi predaje da se može izreći samo ako se time bitno ne ugrožavaju osobni i drugi važni interesi djeteta (čl. 519/2. ObZ) te u postupcima ovrhe radi ostvarivanja osobnih odnosa s djetetom ako je obiteljska medijacija prethodno prošla neuspješno i ako je nužno hitno postupanje (čl. 522/3. ObZ). Mogućnost odgode ovrhe i zasebno je predviđena čl. 524. kojim se ponavlja da sud može odgoditi ovrhu (između ostalog) ako je djetetu naložen stručni razgovor. Dodatni je uvjet za odgodu da se njome bitno ne ugrožavaju osobni i drugi važni interesi djece (čl. 524. ObZ). Ipak, u doktrini se iznosi sumnja u uspješnost prevencije neodmjerenog odgađanja

65 Sudska odluka Županijskog suda u Varaždinu br. Gž Ob-103/15-2 od 19. listopada 2015.

66 Antun Žagar, „Ovrha radi ostvarivanja susreta i druženja roditelja s djetetom“, Zagrebačka pravna revija 2, br. 1 (2013.): 80, https://hrcak.srce.hr/129498.

67 Marina Pavić, Ivan Šimović, Anica Čulo Margaletić, „Postupak ovrhe radi ostvarivanja osobnih odnosa roditelja i djece kao pretkazivač povrede prava iz Europske konvencije za zaštitu ljudskih prava i temeljnih sloboda“, Godišnjak Akademije pravnih znanosti Hrvatske 8 (2017): 193, https://hrcak.srce.hr/191579. 
ovrhe te se iznosi da je olaka primjena tog instituta potencijalno suprotna načelu učinkovite zaštite prava utvrđenog pred ESLJP-om. ${ }^{68}$ Naime, u predmetima koji se tiču provođenja ovrhe odluka iz obiteljskopravnog područja, ESLJP je više puta utvrdio ključnim okolnost jesu li domaće vlasti učinile sve neophodne i razumne mjere kako bi, u skladu s posebnim okolnostima svakog slučaja, olakšale njihovu provedbu. ${ }^{69}$ Prikladnost mjera koje je tužena država poduzela prosuđuje se i s obzirom na brzinu njihove provedbe i brzinu postupanja jer sam protek vremena može imati nepoželjne posljedice na odnose između djeteta i roditelja s kojim dijete ne živi. Dugotrajnost postupka posljedično bi stoga mogla dovesti i do povrede prava na poštovanje obiteljskog života iz članka 8 . EKLJP. ${ }^{70}$ Osim toga, dugotrajnost postupka povrjeđuje i pravo stranke na pošteno suđenje iz članka 6. te Konvencije, budući da je izvršenje sudske odluke, makar ono bilo i prisilno, njegov integralni dio. ${ }^{71}$

\section{ZAKLJUČAK}

Polazna točka ostvarivanja prava na izražavanje mišljenja djeteta najbolji je interes djeteta. Upitno je međutim, je li uvijek u njegovu interesu izlagati ga sudskom postupku i to više puta. Pri donošenju odluke koja utječe na dijete, nužno je provesti razmatranje potencijalnog utjecaja toga postupka na dotično dijete. ${ }^{72}$ Višekratno uključivanje djeteta u sudski postupak, bez diskrecijske mogućnosti suca da procijeni njegovu nužnost, u praksi bi moglo dovesti do nepotrebnog odugovlačenja postupka i (ponovnog!) stavljanja djeteta u stresnu situaciju. U literaturi se često raspravljalo pod kojim uvjetima i u kojoj je dobi dijete dostatno zrelo shvatiti posljedice izražavanja svojeg mišljenja. Izražava se zabrinutost na koji način ostvarivanje tog prava psihološki djeluje na dijete i o mogućim manipulacijama tim pravom. Na opasnost izlaganja djeteta prekomjernom stresu tijekom sudskog više je puta ukazivao i ESLJP. Drugi razlog zbog kojeg u ovršnom postupku možemo smatrati dužnost omogućavanja djetetu izražavanje mišljenja suvišnim, je razlog potrebe provođenja ovršnih postupaka što hitnije i jednostavnije. Postulati su to postavljeni pravilima općeg ovršnog prava, a na njima se inzistira i u sudskoj praksi europskih sudova $\mathrm{i}$ ESLJP-a i Suda EU-a.

U kontekstu prava EU-a, Uredba 2201/2003 izričito zahtijeva da je u sudskom

68 Pavić, Šimović, Čulo Margaletić, Postupak ovrhe radi ostvarivanja osobnih odnosa roditelja $i$ djece kao pretkazivač povrede prava iz Europske konvencije za zaštitu ljudskih prava i temeljnih sloboda, str. 194.

69 Presuda od 25. siječnja 2000., Ignaccolo-Zenide protiv Rumunjske, zahtjev br. 31679/96, para. 96.; presuda od 23. rujna 1994., Hokkanen protiv Finske, zahtjev br. 19823/92, para. 22.

70 Vidi predmete: presuda od 14. lipnja 2011., Zoltán Németh protiv Mađarske, zahtjev br. 29436/05, para. 50. i 56.; presuda od 12. travnja 2011., Gluhaković protiv Hrvatske, zahtjev br. 21188/09, para. 59.; presuda od 15. prosinca 2005., Karadžić protiv Hrvatske, zahtjev br. 35030/04, para. 62.

71 Presuda od 19. ožujka 1997., Hornsby protiv Grčke, zahtjev br. 18357/91, para. 40.; presuda od 15. prosinca 2005., Karadžić protiv Hrvatske, zahtjev br. 35030/04, para. 53. i 58.

72 Jean Zermatten, „Best interests of the child“, u: Child-friendly Justice: A Quarter of a Century of the UN Convention on the Rights of the Child, ur. Said Mahmoudi et al. (Leiden/Boston: Brill Nijhoff, 2015.), 31. 
postupku strankama i djetetu bila pružena mogućnost biti saslušani, osim ako je to s obzirom na djetetovu dob i zrelost u suprotnosti s njegovom dobrobiti. Ipak, to se pravo može ograničiti posebice radi smanjenja izlaganja djeteta stresnim situacijama i tenzijama. Odredbe Uredbe 2201/2003 i odluke Suda EU-a u svezi njih jasno upućuju na intenciju ubrzanja analiziranih postupaka ovrhe u svrhu što učinkovitije zaštite interesa djeteta, a ukidanje dodatnog postupka egzekvature usvojeno je kao „najvažnija inovacija” europske pravosudne suradnje u građanskim stvarima. ${ }^{73}$

Ni ESLJP ne zahtijeva apsolutno provođenje saslušanja djeteta u sudskom postupku. Odluka o saslušanju donosi se prosudbom posebnih okolnosti svakog slučaja te ovisi o djetetovoj zrelosti i dobi. S druge strane, u svojim je presudama više puta naglasio da je u interesu djece da se postupci, u koje su ona uključena, hitno rješavaju jer odugovlačenje i dugotrajnost ovih postupaka može ostaviti nepopravljive posljedice na njihove odnose s roditeljima.

Sukladno hrvatskom ObZ-u u ovršnom postupku radi predaje djeteta sud može odlučiti hoće li saslušati osobu protiv koje se ovrha provodi te, s obzirom na okolnosti slučaja, tijekom postupka ovrhe dijete uputiti na stručni razgovor. Međutim, u postupcima ovrhe radi ostvarivanja osobnih odnosa s djetetom bi se prije donošenja rješenja o ovrsi moralo održati ročište u cilju saslušanja stranaka radi utvrđivanja činjenica i procjene okolnosti konkretnoga slučaja te na kojem bi se omogućilo djetetu da izrazi svoje mišljenje. Doktrina ovu odredbu pozitivno ocjenjuje te iznosi kako je njome ,zakonodavac uveo dašak kontradiktornosti u postupak određivanja ovrhe u obiteljskim stvarima, “74 s čime bi se mogli složiti. Međutim, obvezivanje, umjesto ovlaštenje suda na zakazivanje ročišta i (ponovno) saslušanje stranaka i izražavanje mišljenja djeteta, moguće i pod cijenu odgode ovrhe, možemo smatrati suvišnim. Odlika je ovršnih postupaka njihovo provođenje što hitnije, pa bi u određenim situacijama obveza (ponovnog) saslušanja stranaka i omogućavanja djetetu izražavanje mišljenje mogla dovesti do nepotrebnog odugovlačenja postupka. Pritom ne treba zanemariti činjenicu da će nepotrebno odugovlačenje postupka i ponovno saslušanje u postupku samo dodatno otežati, već ionako često psihički i emocionalno tešku situaciju. ${ }^{75}$ Možemo bez sumnje zaključiti da je u djetetovu najboljem interesu biti saslušano, međutim, u obzir je nužno uzeti sve okolnosti slučaja. Ako je to već učinjeno u postupku koji je prethodio ovršnom te ako njegovo (ponovno) saslušanje nije nužno radi dodatnog razjašnjenja, tada je u njegovi interesu i biti zaštićeno od nepotrebnog ponovnog izlaganja ispitivanju bilo ono izravno na sudu, bilo na stručnom savjetovanju. Ipak, u svrhu određivanja svih okolnosti slučaja, sudu će katkad biti potrebno saslušati stranke i dijete i u ovršnom postupku. Stoga tu mogućnost ne treba apsolutno isključiti, nego ju treba prepustiti diskrecijskoj ocjeni suca isto kao što je

73 Mirela Župan i Martina Drventić, „Prekogranične građanskopravne otmice djece“, u: Prekogranično kretanje djece u Europskoj uniji, ur. Mirela Župan (Osijek: Pravni fakultet Sveučilišta J. J. Strossmayera u Osijeku, 2019.), 373.

74 Pavić, Šimović, Čulo Margaletić, Postupak ovrhe radi ostvarivanja osobnih odnosa roditelja $i$ djece kao pretkazivač povrede prava iz Europske konvencije za zaštitu ljudskih prava i temeljnih sloboda, 180 i 193.

75 Vidi odluku ESLJP-a u presudi od 8. srpnja 2003., Sommerfeld protiv Njemačke [GC], zahtjev br. $31871 / 96$, para. 88 . 
to propisano za ovršne postupke radi predaje djeteta. Pritom, pravo na pristup sudu nipošto ne treba shvatiti u strogom smislu izravnog ispitivanja od strane suca, nego se djetetu, uz uvažavanje njegove dobrobiti i interesa, treba omogućiti izraziti stajalište u prikladnom okruženju u kojem se osjeća sigurno. ${ }^{76}$

\section{Knjige i članci:}

\section{LITERATURA}

1. Aras Kramar, Slađana. „Novi pristup uređenju postupka radi razvoda braka u Hrvatskoj“. U: Aktualnosti građanskog procesnog prava - nacionalna i usporedna pravnoteorijska $i$ praktična dostignuća, zbornik radova s međunarodnog savjetovanja. Ur. Vesna Rijavec, Arsen Janevski, Aleš Galič, Jozo Čizmić, Vesna Lazić Smoljanić, Milijan Sesar, Dinka Šago. 235-267. Split: Sveučilište u Splitu, Pravni fakultet, 2015.

2. Aras Kramar, Slađana i Linda Rajhvan Bulat. „Pravo djeteta na prilagođen postupak“. U: Vodič za ostvarivanje prava djeteta na: - informacije, - izražavanje mišljenja, zastupnika $i$ - prilagođen postupak u sudskim postupcima razvoda braka i o roditeljskoj skrbi. Ur. Slađana Aras Kramar; Aleksandra Korać Graovac, Linda Rajhvan Bulat i Ivana Eterović, 58-71. Zagreb: Hrvatski pravni centar, 2015.

3. Archard, David. Children: Rights and Childhood. London: Routledge, 1993.

4. Bartulović, Željko. Povijest prava i države. I. dio - Opća povijest prava i države. Rijeka: Pravni fakultet Sveučilišta u Rijeci, 2014.

5. Brems, Eva. Human Rights: University and Diversity. Hague: Kluwer Law International, 2001.

6. Couzens, Meda. „Autonomy rights versus parental autonomy“. U: The UN Children's Rights Convention: theory meets practice. Ureds. André Alen, Henry Bosly, Maria De Bie, Johan Vande Lanotte, Fiona Ang, Isabelle Delens-Ravier, Marie Delplace, Charlotte Herman, Didier Reynaert, Valentina Staelens, Alen Riet Steel et al. $2^{\text {nd }}$ ed. Antwerpen, Oxford: Intersentia, 2007.

7. Daly, Aoife. „The right of children to be heard in civil proceedings and the emerging law of the European Court of Human Rights". The International Journal of Human Rights 15, br. 3 (2011): 441-461. https://doi.org/10.1080/13642980903542710

8. Dika, Mihajlo. Građansko ovršno pravo, Opće građansko ovršno pravo. Zagreb: Narodne novine, 2007.

9. Duncan, William. „Action in support of the Hague child abduction convention: A view from the Permanent bureau“. International Law and Politics 33, br. 103 (2001): 103--123. https://heinonline.org/HOL/LandingPage?handle=hein.journals/ nyuilp33\&div $=14 \&$ id $=$ \&page $=$.

10. Freeman, Michael. „Why It Remains Important to Take Children's Rights Seriously“. International Journal of Children's Rights 15, br. 1 (2007): 5-23, https://doi. org/10.1163/092755607X181711.

11. Hemrica, Jantine i Frieda Heyting. „Tacit Notions of Childhood: An Analysis of Discourse about Child Participation in Decision-Making Regarding Arrangements in Case of Parental Divorce“. Childhoods 11, br. 4 (2004): 449-468, https://doi. org/10.1177/0907568204047106.

76 Više v. Slađana Aras Kramar, Linda Rajhvan Bulat, „Pravo djeteta na prilagođen postupak“, u: Vodič za ostvarivanje prava djeteta na: - informacije, - izražavanje mišljenja, - zastupnika $i$ - prilagođen postupak u sudskim postupcima razvoda braka i o roditeljskoj skrbi, ur. Slađana Aras Kramar; et al. (Zagreb: Hrvatski pravni centar, 2015.), 58-71. 
12. Hrabar, Dubravka. „Europska konvencija o ostvarivanju dječjih prava - Poseban zastupnik djeteta“. U: Dijete u pravosudnom postupku - Primjena Europske konvencije o ostvarivanju dječjih prava. Ur. Gordana Filipović, Davorka Osmak- Franjić, 103-116. Zagreb: Pravobranitelj za djecu, 2012.

13. Korać Graovac Aleksandra i Ivana Eterović. „Pravo djeteta na izražavanje mišljenja“. $\mathrm{U}$ : Vodič za ostvarivanje prava djeteta na: - informacije, - izražavanje mišljenja, zastupnika $i$ - prilagođen postupak u sudskim postupcima razvoda braka i o roditeljskoj skrbi. Ur. Slađana Aras Kramar; Aleksandra Korać Graovac, Linda Rajhvan Bulat i Ivana Eterović, 40-41. Zagreb: Hrvatski pravni centar, 2015.

14. Liefaard, Ton. „Child-friendly justice: protection and participation of children in the justice system“. Temple Law Review 88, br. 4 (2016): 905-927. https://www.templelawreview. org/lawreview/assets/uploads/2016/08/Liefaard-88-Temp.-L.-Rev.-905.pdf.

15. Lucić, Nataša. „Protection of the right of the child to be heard in divorce proceedings harmonization of Croatian law with European legal standards". U: Procedural aspects of EU law. Ur. Dunja Duić i Tunjica Petrašević, 391-423. Osijek: Faculty of law Osijek, 2017.

16. Majstorović, Irena. „Ostvarivanje prava djeteta na izražavanje mišljenja - koliko su djeca 'vidljiva' u obiteljskim sudskim postupcima u Hrvatskoj?", Ljetopis socijalnog rada 24, br. 1 (2017): 55-71. https://doi.org/10.3935/ljsr.v24i1.163.

17. O'Donnell, Rebecca „The role of the EU legal and policy framework in strengthening child friendly justice“. ERA Forum 14, br. 4 (2013): 507--521, https://doi.org/10.1007/ s12027-013-0328-6.

18. Odbor za prava djeteta, Opći komentar br. 14 (2013.) o pravu djeteta da njegovi ili njeni najbolji interesi moraju imati prednost (čl. 3., st. 1.). Pristup 18. veljače 2021. https://j4c. ba/wp-content/uploads/2018/02/Opci-komentar-14-najbolji-interes-djeteta.pdf.

19. Pavić, Marina, Ivan Šimović, Anica Čulo Margaletić. „Postupak ovrhe radi ostvarivanja osobnih odnosa roditelja i djece kao pretkazivač povrede prava iz Europske konvencije za zaštitu ljudskih prava i temeljnih sloboda“. Godišnjak Akademije pravnih znanosti Hrvatske 8 (2017): 171-198, https://hrcak.srce.hr/191579.

20. Poretti, Paula. „Pristup pravosuđu za djecu“. U: Prekogranično kretanje djece u Europskoj uniji, ur. Mirela Župan, 61-94. Osijek: Pravni fakultet Sveučilišta J. J. Strossmayera u Osijeku, 2019.

21. Priručnik o pravima djeteta u europskom pravu. Pristup 28. prosinca 2020. https://fra. europa.eu/hr/publication/2020/prirucnik-o-pravima-djeteta-u-europskom-pravu.

22. Rešetar, Branka. „Pravo djeteta na ostvarivanje osobnih odnosa u međunarodnom pravu“. U: Prekogranično kretanje djece u Europskoj uniji, ur. Mirela Župan, 229-258. Osijek: Pravni fakultet Sveučilišta J. J. Strossmayera u Osijeku, 2019.

23. Samuel, Geoffrey. Epistemology and Method in Law. London, New York: Routledge, Taylor \& Francis Group, 2016.

24. Triva, Siniša i Mihajlo Dika. Građansko parnično procesno pravo. Zagreb, Narodne novine, 2004.

25. Van Bueren, Geraldine. Child Rights in Europe: Convergence and Divergence in Judicial Protection. Strasbourg: Council of Europe Publishing, 2007.

26. Van Dijk, Pieter i Fried Van Hoof. Theory and Practice of the European Convention on Human Rights. Haag: Kluwer Law International, 1998.

27. Vandekerckhove, Ankie i Killian O'Brien. „Child-Friendly Justice: turning law into reality“. ERA Forum 14, br. 4 (2013): 523-541, https://doi.org/10.1007/s12027-0130323-y.

28. Young, Ian. The Child Client. Children and Society 6, br. 3 (1992): 187--203, https://doi. org/10.1111/j.1099-0860.1992.tb00586.x. 
29. Zermatten, Jean. „Best interests of the child“. U: Child-friendly Justice: A Quarter of a Century of the UN Convention on the Rights of the Child. Ur. Said Mahmoudi et al., 3042. (Leiden; /Boston: Brill Nijhoff, 2015), 30-42.

30. Žagar, Antun. „Ovrha radi ostvarivanja susreta i druženja roditelja s djetetom“. Zagrebačka pravna revija 2, br. 1 (2013): 75-105, https://hrcak.srce.hr/129498.

31. Župan Mirela i Martina Drventić. „Prekogranične građanskopravne otmice djece“. U: Prekogranično kretanje djece u Europskoj uniji. Ur. Mirela Župan, 345-380. Osijek: Pravni fakultet Sveučilišta J. J. Strossmayera u Osijeku, 2019.

Pravni akti:

1. Europska konvencija o kontaktima s djecom, Narodne novine, br. 7/08.

2. Haška konvencija o građanskopravnim vidovima međunarodne otmice djece, Narodne novine, br. 8/18.

3. Haška konvencija o nadležnosti, mjerodavnom pravu, priznanju, izvršenju i suradnji u vezi s roditeljskom skrbi i mjerama za zaštitu djece, Narodne novine, br. 5/09.

4. Konvencija o pravima djeteta, Službeni list SFRJ, br. 14/90., Narodne novine, Međunarodni ugovori, br. 12/93., 20/97.

5. Konvencija za zaštitu ljudskih prava i temeljnih sloboda, Protokoli br. 1., 4., 6. i 7. uz tu Konvenciju, Narodne novine, Međunarodni ugovori, br. 18/97.

6. Obiteljski zakon, Narodne novine, br. 103/15., 98/19.

7. Obiteljski zakon, Narodne novine, br. 116/03., 17/04., 106/04., 136/04., 107/07., 57/11., 61/11., 25/13.

8. Ovršni zakon, Narodne novine br. 112/12., 25/13., 93/14., 55/16., 73/17., 131/20.

9. Povelja Europske unije o temeljnim pravima, 2012/C 326/02, SL C 326 od 26.10. 2012, str. 391-407.

10. UN Committee on the Rights of the Child (CRC), General comment No 12 (2009): The right of the child to be heard, 20 July $2009, \mathrm{CRC} / \mathrm{C} / \mathrm{GC} / 12$.

11. Uredba Vijeća (EZ) br. 2201/2003 od 27. studenoga 2003. o nadležnosti, priznavanju i izvršenju sudskih odluka u bračnim sporovima i u stvarima povezanim s roditeljskom odgovornošću, kojom se stavlja izvan snage Uredba (EZ) br. 1347/2000, SL L 338, 23.12. 2003, p. 1-29.

12. Uredba Vijeća (EU) 2019/1111 od 25. lipnja 2019. o nadležnosti, priznavanju i izvršenju odluka u bračnim sporovima i u stvarima povezanima s roditeljskom odgovornošću te o međunarodnoj otmici djece (Preinaka) SL EU L 178/1. od 2.7.2019, p. 1-115.

13. Ustav Republike Hrvatske, Narodne novine, br. 85/10., 05/14.

14. Zakon o parničnom postupku, Narodne novine, br. 53/91., 91/92., 112/99., 129/00., 88/01., 117/03., 88/05., 2/07., 96/08., 84/08., 123/08., 57/11., 25/13., 89/14., 70/19.

15. Pravilnik o načinu utvrđivanja mišljenja djeteta, Narodne novine, br. 106/14., 5/15., 28/16., 103/15., 123/15.

Sudska praksa:

1. Presuda ESLJP od 12. travnja 2011., Gluhaković protiv Hrvatske, zahtjev br. 21188/09.

2. Presuda ESLJP od 14. lipnja 2011., Zoltán Németh protiv Mađarske, zahtjev br. 29436/05.

3. Presuda ESLJP od 15. prosinca 2005., Karadžić protiv Hrvatske, zahtjev br. 35030/04.

4. Presuda ESLJP od 19. ožujka 1997., Hornsby protiv Grčke, zahtjev br. 18357/91.

5. Presuda ESLJP od 23. rujna 1994., Hokkanen protiv Finske, zahtjev br. 19823/92.

6. Presuda ESLJP od 25. siječnja 2000., Ignaccolo-Zenide protiv Rumunjske, zahtjev br. 31679/96.

7. Presuda ESLJP od 26. lipnja 2003., Maire protiv Portugala, zahtjev br. 48206/99.

8. Presuda ESLJP od 26. veljače 2002., Kutzner protiv Njemačke, zahtjev br. 46544/99.

9. Presuda ESLJP od 7. ožujka 2013., Raw protiv Francuske, zahtjev br. 10131/11. 
10. Presuda ESLJP od 8. srpnja 2003., Sahin protiv Njemačke [GC], zahtjev br. 30943/96.

11. Presuda ESLJP od 8. srpnja 2003., Sommerfeld protiv Njemačke [GC], zahtjev br. $31871 / 96$.

12. Presuda Suda EU od 1. srpnja 2010., Doris Povse protiv Mauro Alpago, C-211/10, ECLI:EU:C:2010:400.

13. Presuda Suda EU od 22. prosinca 2010. Aguirre Zarraga v Pelza, Case C-491/10 [2010] ECR I-14247.

14. Presuda Suda EU od 22. prosinca 2010., Joseba Andoni Aguirre Zarraga protiv Simone Pelz, C-491/10 PPU, ECLI:EU:C:2010:828.

15. Presuda Suda EU od 5. listopada 2010. McB v L.E., Case C-400/10 [2010] ECR I-8965.

16. Presuda Županijskog sud u Zagrebu od 27. prosinca 2019., br. Gž Ob 1371/2019-2.

17. Presuda Županijskog suda u Varaždinu od 19. listopada 2015., br. Gž Ob-103/15-2.

18. Presuda Županijskog suda u Zagrebu od 10. svibnja 2016. br. Gž Ob-600/16.

19. Presuda Županijskog suda u Bjelovaru od 26. ožujka 2009., br.: Gž-278/09-2. 


\section{Katarina Knol Radoja*}

Summary

\section{THE RIGHT TO BE HEARD AND TO EXPRESS OPINION IN SPECIAL ENFORCEMENT PROCEEDINGS FOR THE RETURN OF THE CHILD AND THE ESTABLISHMENT OF PERSONAL RELATION WITH THE CHILD}

In this paper we have analyzed the international regulations and case law of the European Court of Human Rights and the Court of Justice of the European Union and the provisions of the Croatian Family Law regarding the right to be heard and express the opinion of a child in enforcement proceedings for the return of the child and the establishment of personal relation with the child. According to this Act, in the procedure for the return of the child, the court may, before determining the means of enforcement, hear the person against whom enforcement is being carried out. Concerning the child's right to express an opinion in these proceedings, it is prescribed that the court may, given the circumstances of the case during the enforcement proceedings, refer the child for an interview with an expert. On the other hand, in the enforcement procedure to establish personal relations with the child, the court is obliged to schedule a hearing before issuing a decision at which it will personally hear the parties establish the facts and assess all circumstances and is obliged to allow the child to express an opinion. In conclusion, it is stated that enforcement proceedings, especially due to their nature (personal and emotional), should be urgent and as simple as possible. During their implementation, the child, as well as the parties to the proceedings, should not be absolutely prevented from exercising the right to be heard and express an opinion, however, the court should not be obliged to hold a hearing to hear the party and allow the child to express an opinion unless if this is not necessary to clarify the case. This should depend on the discretion of the court given the circumstances of the case and taking into account the welfare of the child. The author of the paper therefore proposes amending the provision on hearing in proceedings to establish a personal relationship with the child so that the enforcement court may and not has to hear the parties and allow the child to express opinion, all to protect the interests and welfare of the child.

Keywords: right to be heard; right of the child to express an opinion; right of access to court; special enforcement proceedings.

* Katarina Knol Radoja, Ph.D., Assistant Professor, Faculty of law, J. J. Strossmayer University of Osijek; kknol@pravos.hr. ORCID: https://orcid.org/0000-0003-0275-3076. 
